\title{
UTERINE RESPONSE TO OVARIECTOMY DURING THE PROLIFERATIVE AND LUTEAL PHASES IN THE MARSUPIAL, TRICHOSURUS VULPECULA
}

\author{
C. D. SHOREY* AND R. L. HUGHES \\ Electron Microscope Unit, University of Sydney, N.S.W. 2006, and \\ School of Zoology, University of South Wales, \\ P.O. Box 1, Kensington, N.S.W. 2033, Australia
}

(Received 25th March 1974)

\begin{abstract}
Summary. The uterine luteal phase in $T$. vulpecula is not dependent upon the secretions of the GL throughout its duration. Ablation of the CL or ovariectomy after Day 7 of the 26-day oestrous cycle does not result in the termination of the uterine secretory phase. The dependence of the luteal phase on the secretions of the CL is demonstrated by ablation of the CL or ovariectomy on Days 2, 4, 8, 12 and 24 of the oestrous cycle. Ablation of the CL before Day 8 resulted in the inhibition of the impending luteal phase, and the commencement of a follicular phase resulting in oestrus 8 to 9 days later. Removal of the CL or ovariectomy on Days 8 or 12 does not completely inhibit the uterine luteal phase since sufficient precursor of uterine milk is stored in the uterine basal glandular epithelium, thus enabling the endometrium to maintain the secretion of uterine milk.
\end{abstract}

\section{INTRODUCTION}

Histological studies of several marsupials (Hill \& O'Donoghue, 1913; Hartman, 1923; Sharman, 1955a, b; Hughes, 1962a; Pilton \& Sharman, 1962; Tyndale-Biscoe, 1963, 1970; Shorey \& Hughes, 1973a, b) have demonstrated the close correlation between growth and development of the CL, and the initiation and maintenance of the uterine luteal phase. Similar observations have been made in Trichosurus vulpecula, the brush-tailed possum, in which the hormonal control of the oestrous cycle and pregnancy appears to be similar (Shorey \& Hughes, 1973a, b). In all kangaroo-like marsupials, however, the CL degenerates well before birth, which is followed by a post-partum oestrus (Hughes, 1962b). In T. vulpecula, parturition coincides with the early involution of the CL and the termination of the uterine luteal phase (Shorey \& Hughes, 1973b). Pilton \& Sharman (1962) indicated that, although the uterine luteal phase appeared dependent throughout its duration upon the secretions of the GL, there was some evidence (not given) to indicate that this was not the

* Present address: Department of Histology and Embryology, University of Sydney, N.S.W. 2006, Australia. 
case. Tyndale-Biscoe (1963) demonstrated in the quokka (Setonix brachyurus) that the uterine luteal phase is dependent only in its initial stages upon the secretions of the GL. The present paper demonstrates the conditions in which the uterine luteal phase will persist in $T$. vulpecula in the absence of an active CL or the ovaries.

\section{Animals}

\section{MATERIALS AND METHODS}

Forty-six mature female brush-tailed possums were used during the course of this work, other details of which have been reported (Shorey \& Hughes, $1973 a$, b). The animals were caught in the wild from early March until late May during the main breeding season in the Sydney metropolitan area. Captured animals were housed individually in cages and fed a diet

Days of the cestrous cycle

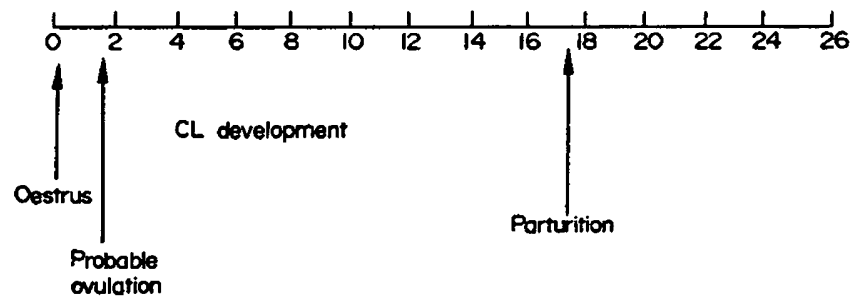

Pro-oestrus

Gestation

\begin{tabular}{lll}
\hline $\begin{array}{l}\text { Proliferative } \\
\text { phose of the } \\
\text { uterine endometrium }\end{array}$ & $\begin{array}{l}\text { Uterine luteal } \\
\text { phose }\end{array}$ & $\begin{array}{l}\text { Follicular } \\
\text { phase }\end{array}$ \\
& &
\end{tabular}

Text-Fig. 1. Diagram to show the events of the oestrous cycle of the brush-tailed possum, Trichosurus vulpecula.

of fresh fruit supplemented by peanut butter and bread. Water was freely available but rarely taken. Each animal was weighed regularly during captivity; individual weights ranged from 1.9 to $3.2 \mathrm{~kg}$ with a mean of $2.4 \mathrm{~kg}$, and did not alter significantly. Pouch young were removed on the day of capture, and oestrus occurred about 8 to 9 days later. During the breeding season, females are polyoestrous with a cycle of about 26 days if a sucking young is not in the pouch (Pilton \& Sharman, 1962). Oestrus was detected by examination of a daily vaginal smear, and was identified by an increase in the number of epithelial cells followed by an invasion of polymorphonuclear leucocytes into the smear the next day. Thus, oestrus was taken as Day 0 and the first appearance of leucocytes in the vaginal smear as Day 1. Individual cycles were staged accordingly and the events are summarized in Text-fig. 1. Ovulation usually occurs by Day 2 after oestrus. The proliferative phase of the uterine endome- 
trium coincides with the development of the Graafian follicle from about Day 22 of the preceding oestrous cycle until a few days after ovulation. The developing CL is evident shortly after ovulation, and by Day 4 it is well differentiated. The uterine luteal phase extends from Day 8 to about Day 16 during which time the basal uterine gland cells are active in the secretion of uterine milk. Parturition occurs on the 18th day of the oestrous cycle, and a Graafian follicle matures in 8 to 9 days if the pouch is emptied or mating does not occur.

\section{Surgical procedures}

Females at a known stage of the cycle were lightly anaesthetized with ether and most of the ventral surface, including the pouch, was shaved and then washed with disinfectant. After full anaesthesia with 'Inactin' (5-aethyl-5(1-methyl-propyl)-2-thio-barbituric acid), which was used $(70 \mathrm{mg} / \mathrm{kg}$ body weight) because it did not cause respiratory failure, a longitudinal mid-line incision was made through the skin and peritoneal wall commencing just inside the pouch and extending in an anterior direction for about $5 \mathrm{~cm}$. The incision was held open by retractors and the ovaries were exposed in turn. The CL were removed by cautery and ovaries were excised after ligation of the blood vessels. The site was sprayed with an antibiotic powder and the peritoneum and muscle layers were sutured with surgical cat-gut and the skin with surgical silk.

Ablation of the CL or ovariectomy was carried out on a series of females to coincide with significant stages of the oestrous cycle (Text-fig. 1). The stages selected were at Days 2, 4, 6 and 7, during the pre-luteal phase, Day 8, the first day of the uterine secretory phase, and Day 12 when the uterine endometrium is maximally secretory. Subsequent structural and ultrastructural analyses of the condition of the uterine endometrium following the surgical procedures were made on the equivalent Day 12 or Day 24, the latter stage coinciding with the uterine proliferative phase, in normal animals. The purpose of these experimental procedures was to evaluate the dependence of the endometrial secretory phase upon the $\mathrm{CL}$ and ovaries (Table 1).

Following anaesthesia with 'Inactin', peripheral blood samples were collected from a catheter inserted into the femoral artery. Ovarian blood samples were collected from the utero-ovarian vein (Shorey \& Hughes, 1973a, b). Females which had been used for the progesterone determinations were not used for the morphological studies.

\section{Light and electron microscopy}

For light microscopy, reproductive organs were fixed in Bodian's fixative. Routine staining was carried out with Weigert's iron haematoxylin and methylene blue. Tissue processed for electron microscopy was fixed in either $2.5 \%$ glutaraldehyde in $0.1 \mathrm{M}$-cacodylate buffer at $\mathrm{pH} 7.2$ or Karnovsky's (1965) glutaraldehyde-formaldehyde fixative. Post-fixation was carried out in $1 \%$ osmium tetroxide in veronal buffer. Sections were stained with uranyl acetate and lead citrate (Venable \& Coggeshall, 1965) and examined in a Philips EM 300 electron microscope. 
Table 1. The effects of ablation of the CL or ovariectomy of the brush-tailed possum, Trichosurus vulpecula, at different stages of the oestrous cycle

\begin{tabular}{|c|c|c|c|c|}
\hline \multicolumn{2}{|r|}{ Surgical procedure } & \multirow{2}{*}{$\begin{array}{c}\text { Day } \\
\text { killed } \\
\text { after } \\
\text { operation }\end{array}$} & \multirow{2}{*}{$\begin{array}{l}\text { Equivalent } \\
\text { day of } \\
\text { normal } \\
\text { oestrous } \\
\text { cycle }\end{array}$} & \multirow[b]{2}{*}{ Macroscopic observations } \\
\hline $\begin{array}{c}\text { Day of } \\
\text { oestrous } \\
\text { cycle }\end{array}$ & Ablation & & & \\
\hline 2 & 2.7-mm CL from L.O. & 10 & 12 & $\begin{array}{l}\text { Uteri appeared pale and not highly } \\
\text { vascularized. The endometrium was } \\
\text { not in a luteal condition. Vaginal } \\
\text { smear was typically post-oestrous and } \\
\text { consisted of cornified epithelial celis } \\
\text { and polymorphonuclear leucocytes. }\end{array}$ \\
\hline 2 & 2.5-mm CL from R.O. & 10 & 12 & Post-oestrous vaginal smear. \\
\hline 2 & $\begin{array}{l}\text { L.O. with 4.7-mm foll. }+ \\
\text { R.O. }\end{array}$ & 10 & 12 & $\begin{array}{l}\text { Uteri were small and the endometrium } \\
\text { had not proliferated. }\end{array}$ \\
\hline 4 & 4·4-mm GL from L.O. & 8 & 12 & $\begin{array}{l}\text { Uteri had regressed from the Day- } 4 \\
\text { condition. The endometrium was not } \\
\text { luteal. }\end{array}$ \\
\hline 4 & R.O. with $1.5-\mathrm{mm} \mathrm{CL}$ & 8 & 12 & $\begin{array}{l}\text { Left uterus appeared pale and flaccid. } \\
\text { The endometrium was dry. The right } \\
\text { uterus was smaller in size. The endo- } \\
\text { metrium was proliferated but not } \\
\text { luteal. }\end{array}$ \\
\hline 4 & $\begin{array}{l}\text { L.O. with 2.5-mm CL }+ \\
\text { R.O. }\end{array}$ & 8 & 12 & $\begin{array}{l}\text { Both uteri regressed from a well vascu- } \\
\text { larized and enlarged condition to being } \\
\text { pale and flaccid. The endometrium } \\
\text { was not proliferated. }\end{array}$ \\
\hline 8 & 4.5-mm CL from R.O. & 4 & 12 & $\begin{array}{l}\text { Both uteri appeared enlarged and well } \\
\text { vascularized. No apparent regression } \\
\text { of the endometrium from the 8-day } \\
\text { stage. }\end{array}$ \\
\hline 8 & L.O. with $3 \cdot 8-\mathrm{mm} \mathrm{GL}$ & 4 & 12 & As above. \\
\hline 8 & $\begin{array}{l}\text { R.O. with } 4 \cdot 1-\mathrm{mm} \mathrm{CL}+ \\
\text { R.O. }\end{array}$ & 4 & 12 & As above. \\
\hline 12 & L.O. with $4 \cdot 0-\mathrm{mm} \mathrm{GL}$ & 12 & 24 & $\begin{array}{l}\text { 3-mm follicle on the right ovary. } \\
\text { Reproductive tract in a typically pro- } \\
\text { oestrous condition, confirmed by } \\
\text { vaginal smear. }\end{array}$ \\
\hline 12 & 4.5-mm CL from R.O. & 12 & 24 & Pro-oestrous vaginal smear. \\
\hline 12 & $\begin{array}{l}\text { R.O. with 5.4-mm CL+ } \\
\text { L.O. }\end{array}$ & 12 & 24 & $\begin{array}{l}\text { The uteri had regressed from a highly } \\
\text { vascularized and enlarged condition to } \\
\text { a typically anoestrous condition. }\end{array}$ \\
\hline 7 & R.O. & 5 & 12 & $\begin{array}{l}\text { 3.5-mm CL on L.O. Uteri were en- } \\
\text { larged and well vascularized and } \\
\text { typical of the mid-luteal condition. }\end{array}$ \\
\hline 6 & $\begin{array}{l}\text { 3.5-mm CL from L.O. } \\
\text { 2.8-mm CL from L.O. } \\
\text { 3-2-mm CL from R.O. }\end{array}$ & $\begin{array}{l}- \\
-\end{array}$ & $\begin{array}{l}- \\
-\end{array}$ & $\begin{array}{l}\text { Vaginal smear confirmed oestrus } \\
9 \text { days after GL was removed. } \\
\text { Laparotomy revealed reproductive } \\
\text { tract was typical for female in oestrus. }\end{array}$ \\
\hline 7 & $\begin{array}{l}\text { 3.8-mm CL from L.O. } \\
\text { 2.7-mm CL from R.O. } \\
\text { 3.0-mm CL from L.O. }\end{array}$ & - & - & $\begin{array}{l}\text { Vaginal smear confirmed oestrus } 9 \text { days } \\
\text { after } G L \text { was removed. } \\
\text { In one female, two CL were present } \\
\text { on the L.O. Uteri were enlarged and } \\
\text { well vascularized. }\end{array}$ \\
\hline
\end{tabular}

$\mathrm{CL}=$ corpus luteum; R.O. = right ovary; L.O. = left ovary. 


\section{RESULTS}

\section{Animals killed on Day 12 after oestrus}

Surgery on Day 2. Ablation of the CL or ovariectomy on Day 2 (Table 1) prevented the development of the uterine luteal phase. At autopsy, the condition of the animals was characteristic of that immediately after oestrus (Table 1). The thickness of the uterine endometrium 10 days after surgery averaged $1.5 \mathrm{~mm}$ compared with $4.2 \mathrm{~mm}$ in a normal female on Day 12. The glandular epithelial cell height of 12 to $14 \mu \mathrm{m}$ (P1. 1, Fig. 1) corresponded to the equivalent epithelial height in intact animals between Days 0 and 2 of the oestrous cycle (Shorey \& Hughes, 1973a). When both ovaries were removed (Table 1), regression of the uterine glandular epithelium was apparent, and many of these epithelial cells contained areas of cytoplasmic degradation incorporating large lysosome-like structures (P1. 1, Figs 2 and 3).

Surgery on Day 4. Ovariectomy or ablation of the GL on Day 4 of the cycle also prevented the development of the uterine secretory phase (Table 1). The uterine endometrium was about $1.5 \mathrm{~mm}$ thick compared with $4.2 \mathrm{~mm}$ in an intact animal on Day 12. Structural and ultrastructural examination of the uterine glands demonstrated that there was no secretory activity in the glandular epithelial cells (Pl. 1, Fig. 4). The average cell height of $14 \mu \mathrm{m}$ corresponded to that measured in normally cyclic animals during the mid-proliferative phase when no accumulations of secretory material are stored in the cytoplasm (Shorey \& Hughes, 1973a).

Surgery on Days 6 and 7. Ablation of the CL on Days 6 and 7 of the oestrous cycle prevented the development of the uterine luteal phase. Mitotic activity was apparent in the uterine endometrium, and oestrus occurred in all the animals 9 days after surgery (Table 1 ). Removal of the ovary not bearing the CL did not restrict the development of the uterine luteal phase. Subsequent histological studies carried out on Day 12 of the same cycle revealed that both uteri were in a luteal condition with basal gland heights equivalent to those in intact animals.

Surgery on Day 8. Removal of the ovary bearing the GL, bilateral ovariectomy, or ablation of the CL did not result in the termination of the uterine luteal phase (Table 1), although the proliferation of the endometrium was not as great as in normal females on Day 12 . The average thickness of the endometrium in the females subjected to operation was $2.7 \mathrm{~mm}$ compared with $4.2 \mathrm{~mm}$ in intact animals. Accumulations of secretory material in the basal uterine gland cells were evident, but the glandular epithelium had not proliferated to the extent normally associated with an endometrium 12 days after oestrus (P1. 2, Fig. 5). Removal of the CL or of the ovary bearing the CL resulted in the height of the epithelial cells of the basal glands being $50 \mu \mathrm{m}$ compared to $55 \mu \mathrm{m}$ in normal animals. Bilateral ovariectomy caused some vacuolization in the basal glandular epithelium and the epithelial height was reduced to $43 \mu \mathrm{m}$ (Pl. 2, Fig. 6).

Ultrastructural examination of the basal uterine glands following ovariectomy confirmed the existence of accumulated secretory product ( $\mathrm{Pl}$. 2, Fig. 7). It was evident, however, that the synthesis of the secretory product was not 
completed, as indicated by the dilated cisternae of rough endoplasmic reticulum in the basal regions of many of these cells. In normal Day- 12 females, the basal uterine gland cells were filled with the secretory product, and no rough endoplasmic reticulum was apparent (Shorey \& Hughes, 1973a).

\section{Animals killed 24 days after oestrus}

Surgery on Day 12. Females unilaterally and bilaterally ovariectomized during the mid-luteal phase on Day 12 of the oestrous cycle were killed 12 days later to coincide with the uterine proliferative phase on Day 24 of the oestrous cycle (Table 1). In the bilaterally ovariectomized females, the endometrium regressed to an average thickness of $1.0 \mathrm{~mm}$ compared with $1.5 \mathrm{~mm}$ in control or unilaterally ovariectomized animals, in which also mitoses were common in the basal gland cells (Pl. 2, Fig. 8). Ultrastructurally, the basal uterine gland cells were similar to those in control animals on Day 24 of the oestrous cycle (Shorey \& Hughes 1973a); the cells were about $14 \mu \mathrm{m}$ high in control and unilaterally ovariectomized animals, and $9 \mu \mathrm{m}$ in the bilaterally ovariectomized animals. The cells in the bilaterally ovariectomized females had lower cytoplasmic activity, as indicated by condensed Golgi bodies, the relatively smaller structureless mitochondria, and the absence of rough endoplasmic reticulum (Pl. 3, Fig. 9). The majority of cells in the basal regions of the uterine glands in the ovariectomized and control animals were ciliated and few secretory cells were apparent.

Blood samples taken before removal of the CL on Day 7 of the oestrous cycle, showed that there was a mean concentration of $62.7 \mathrm{ng}$ progesterone $/ \mathrm{ml}$

\section{EXPLANATION OF PLATES 1 TO 3}

All figures show basal uterine gland tissue from brush-tailed possums.

PLATE 1

Fig. 1. A cross-section through the basal uterine glands (G) 12 days after oestrus and 10 days after ablation of the CL on Day 2. Secretory material is not present in the glandular epithelial cells. $\times 1050$.

Fig. 2. Gland cell 12 days after oestrus and 10 days after ovariectomy on Day 2 showing early cytoplasmic degradation (arrowed). $\times 9700$.

Fig. 3. Gland cell incorporating a lysosome-like structure (LY) 10 days after ovariectomy. $\times 12,150$.

Fig. 4. Gland 12 days after oestrus and 8 days after ovariectomy on Day 4 of the cycle. No secretory material is stored in the gland cells. $\times 2150$.

PLATE 2

Fig. 5. Gland 12 days after oestrus and following ablation of the CL on Day 8 of the cycle. Secretory material (arrowed) is stored in the cytoplasm of the glandular epithelial cells. $\times 500$.

Fig. 6. Gland 12 days after oestrus and after ovariectomy on Day 8 of the cycle. Secretory material (arrowed) is stored in the cytoplasm of the glandular epithelial cells. $\times 350$. Fic. 7. Gland cells showing accumulated secretory product (SP) and dilated endoplasmic reticulum $(\mathrm{ER})$ below the nucleus $(\mathrm{N}) . \times 6400$.

Fig. 8. Gland cells 24 days after oestrus and 12 days after ablation of the CL. A mitotic figure is arrowed. $\times 350$.

\section{PLATE 3}

Fig. 9. Gland cells 24 days after oestrus and 12 days after ovariectomy. C, cilium; $\mathrm{N}$, nucleus; $\mathrm{M}$, mitochondria; $\mathrm{G}$, Golgi complex. $\times 10,500$. 
P.ATE 1

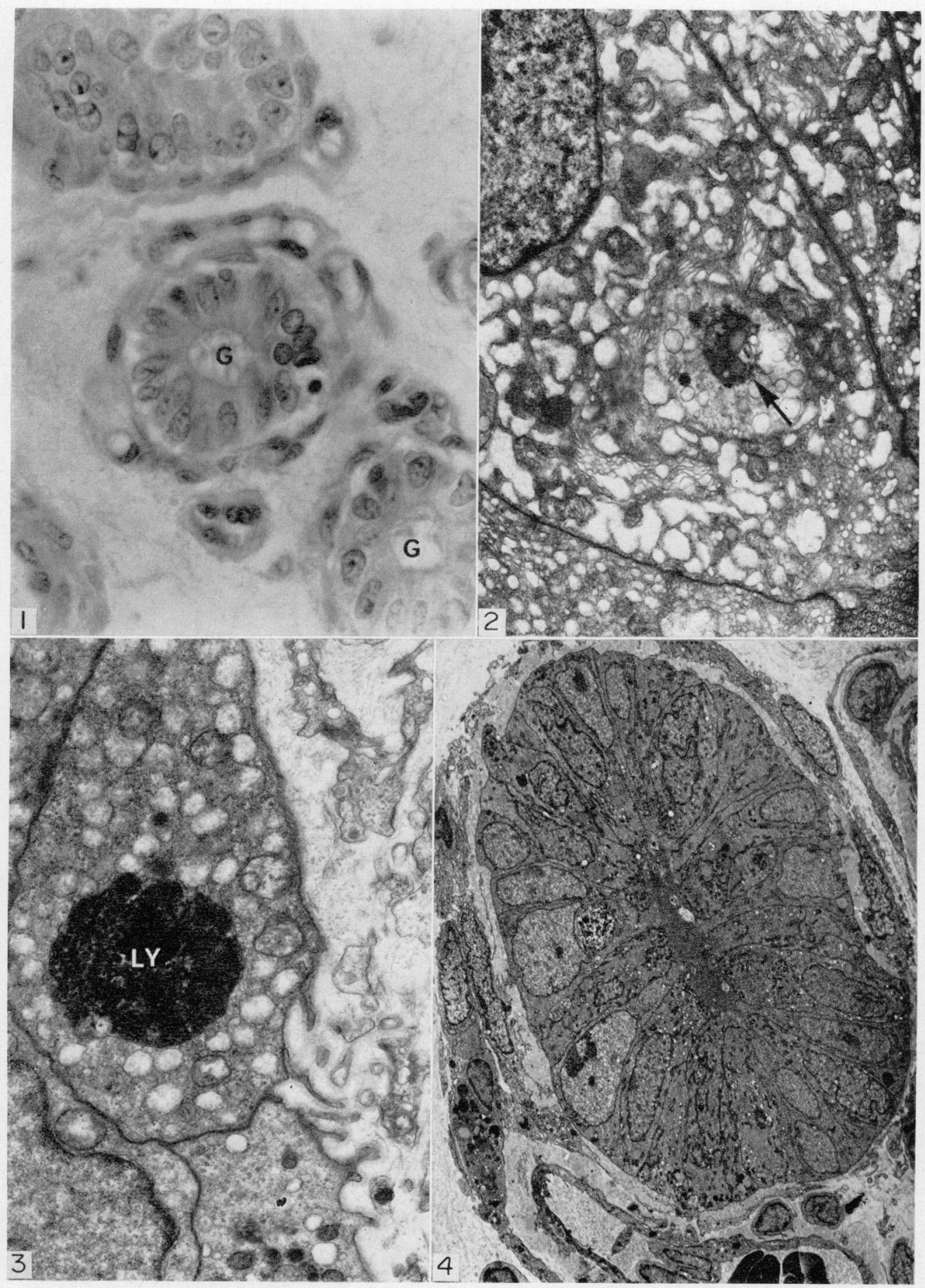

(faring f. 226 ; 


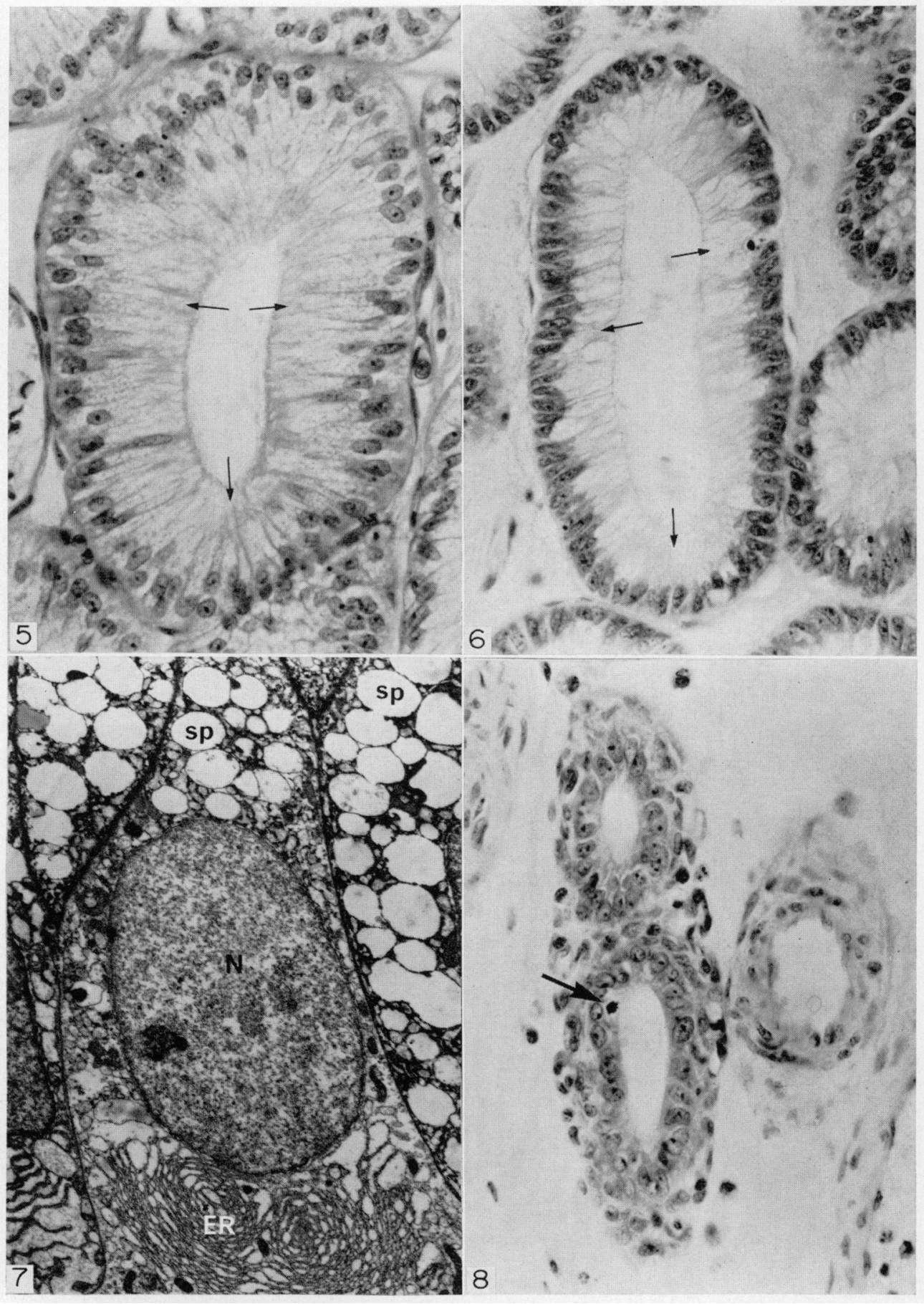


PI.ITI: 3

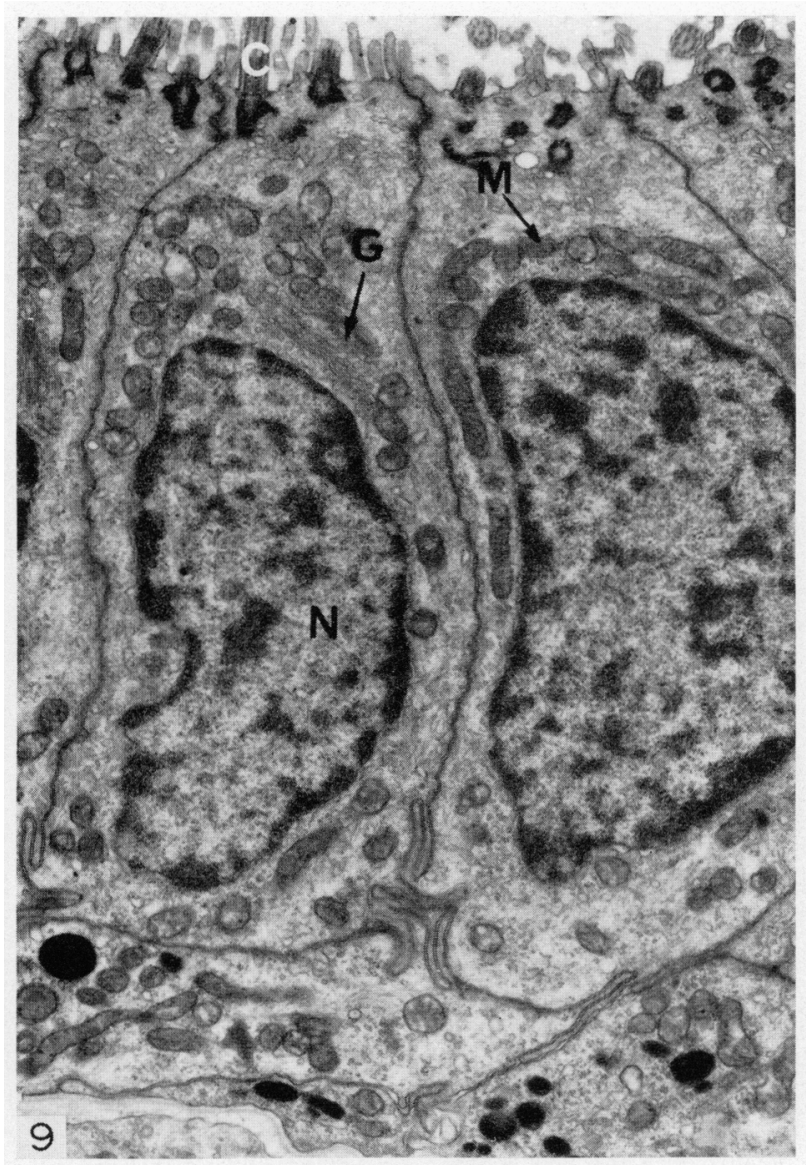


plasma in the utero-ovarian vein and an ovarian secretion rate of $18.62 \mathrm{ng}$ progesterone/min. The peripheral concentration of progesterone at this time was $0.7 \mathrm{ng} / \mathrm{ml}$ (Shorey \& Hughes 1973a, b). The concentration of progesterone in the utero-ovarian vein $30 \mathrm{~min}$ after ablation of the CL was reduced to an average of $18.5 \mathrm{ng} / \mathrm{ml}$ and the ovarian secretion rate had dropped to 1.10 $\mathrm{ng} / \mathrm{min}$. The peripheral plasma concentration of progesterone was reduced to $0.4 \mathrm{ng} / \mathrm{ml}$.

\section{DISCUSSION}

The pattern of progesterone secretion by the $\mathrm{CL}$ and the subsequent concentrations of this hormone in the peripheral blood plasma in T. vulpecula have previously been reported (Shorey \& Hughes 1973a, b). It is evident from these reports that up to the commencement of the luteal phase on Day 8 of the cycle, the peripheral concentrations of progesterone are relatively low and are less than $1 \mathrm{ng} / \mathrm{ml}$ blood plasma. On Day 8, which is the first day of the uterine luteal phase, there is a sharp rise in progesterone concentration to an average of $1.3 \mathrm{ng} / \mathrm{ml}$. This rises to a maximum of $4.5 \mathrm{ng} / \mathrm{ml}$ on Day 12 (Shorey \& Hughes, 1973a).

The results reported in this communication demonstrate that during the period of relatively low progesterone concentration between Days 0 and 7 of the cycle, accumulations of secretory product in the basal uterine gland cells do not occur. Ablation of the CL or unilateral ovariectomy during this period results in lowering of the peripheral plasma concentration of progesterone to levels which are comparable to those found in anoestrous animals (Shorey \& Hughes, 1973a, b), and the commencement of a follicular phase with subsequent ovulation 8 to 9 days later. If the GL is removed between the 8th and 12th day of the oestrous cycle, when relatively high progesterone concentrations activate increased synthesis and accumulation of secretory product in the basal uterine gland cells, the luteal phase is not completely inhibited. It is apparent from structural and ultrastructural observations, however, that synthesis of the uterine milk precursor does not continue in the absence of progesterone, and that the ensuing uterine luteal phase is maintained by the secretory material stored in the gland cells whilst under the influence of progesterone.

Tyndale-Biscoe (1963) examined the physiological mechanisms involved in the maintenance of the uterine luteal phase and pregnancy in the quokka (Setonix brachyurus) after ablation of the CL or ovariectomy. In pregnant and non-pregnant animals, there was the same inhibition of ovulation and persistence of the luteal phase in the uterus after ovariectomy, suggesting that the CL can wholly fulfil its functions by Day 7 and is not necessary for the subsequent progress of pregnancy. The two possible explanations put forward were that either the ovarian secretions remained active and in circulation for much longer periods than previously demonstrated, or that the reproductive cycle of Setonix had only to be initiated by the ovaries and could thereafter continue without further secretions from them. The present work has examined both these possibilities in $\mathcal{T}$. vulpecula.

The plasma assays made it clear that progesterone does not persist for long 
periods in the peripheral circulation. The storage and secretion of uterine milk in the basal uterine glands does not occur until Day 8 of the cycle when the peripheral concentration of progesterone is approximately $1.3 \mathrm{ng} / \mathrm{ml}$, and proliferation of the endometrium does not occur when the peripheral progesterone concentration is less than $1 \mathrm{ng} / \mathrm{ml}$. The uterine luteal phase will only be maintained following ablation of the CL or bilateral ovariectomy when sufficient precursor of uterine milk has been synthesized and stored in the basal glandular epithelial cells of the endometrium. In $T$. vulpecula, synthesis of the uterine milk appears to be dependent upon the CL secreting enough progesterone to increase the peripheral plasma concentrations sufficiently to stimulate the endometrium. Once the uterine milk is stored, it can then progressively be released during the remainder of the luteal phase. When ablation of the CL or bilateral ovariectomy is carried out before the progesterone can reach a high enough concentration in the peripheral plasma to activate the endometrium, a luteal phase does not develop. A follicular phase commences and is followed by the onset of the next oestrus and subsequent ovulation.

Ablation of the CL or bilateral ovariectomy after Day 7 of the cycle does not result in premature ovulation and the uterine luteal phase extends over the normal duration, although the normal level of secretory activity does not appear to be maintained. Synthesis of uterine milk ceases and the endometrium does not proliferate, indicating that the uterine luteal phase is being maintained by the uterine milk synthesized by the glandular epithelium during progesterone stimulation. It is not clear, however, why follicular growth and ovulation can be inhibited by removal of the CL on, but not after, Day 7 of the oestrous cycle.

\section{REFERENCES}

Hartman, G. C. (1923) The oestrous cycle in the opossum. Am. F. Anat. 32, 352-421.

Hitl, J. P. \& O'Donoghue, C. H. (1913) The reproductive cycle in the marsupial Dasyurus viverrinus. Q.7. microsc. Sci. 59, 133-174.

Hugres, R. L. (1962a) Role of the corpus luteum in marsupial reproduction. Nature, Lond. 194, 890891.

Hughes, R. L. (1962b) Reproduction in the macropod marsupial Potorous tridactylus (Kerr). Aust. $\mathcal{J}$. Zool. 10, 193-224.

KaRNovsKy, M. J. (1965) A formaldehyde-glutaraldehyde fixative of high osmolarity for use with electron microscopy. F. Cell Biol. 27, 137a.

Pilton, P. E. \& Sharman, G. B. (1962) Reproduction in the marsupial Trichosurus vulpecula. F. Endocr. 25, 119-136.

Sharman, G. B. (1955a) Studies on marsupial reproduction. 2. The oestrous cycle of Setonix brachyurus. Aust. F. Zool. 3, 44-55.

Sharman, G. B. (1955b) Studies on marsupial reproduction. 3. Normal and delayed pregnancy in Setonix brachyurus. Aust. F. Zool. 3, 56-70.

SHORey, C. D. \& Hughes, R. L. (1973a) Cyclical changes in the uterine endometrium and peripheral plasma concentrations of progesterone in the marsupial Trichosurus vulpecula. Aust. F. Zool. 21, 1-20.

Shorey, C. D. \& Hughes, R. L. (1973b) Development, function and regression of the corpus luteum in the marsupial Trichosurus vulpecula. Aust. F. Zool. 21, 477-489.

Tyndale-Biscoe, C. H. (1963) Effects of ovariectomy in the marsupial Setonix brachyurus. F. Reprod. Fert. 6, 25-40.

Tyndale-Biscoe, G. H. (1970) Resumption of development by quiescent blastocysts transferred to primed, ovariectomized recipients in the marsupial Macropus eugenii. F. Reprod. Fert. 23, 25-32.

VenABLE, J. H. \& Coggeshall, R. (1965) A simplified lead citrate stain for use in electron microscopy. 7. Cell Biol. 25, 407-408. 